\title{
$\left.{ }^{3} \mathrm{H}\right]-\mathrm{SCH} 58261$ labelling of functional $\mathrm{A}_{2 \mathrm{~A}}$ adenosine receptors in human neutrophil membranes
}

\author{
Katia Varani, Stefania Gessi, ${ }^{1}$ Silvio Dionisotti, ${ }^{1}$ Ennio Ongini \& ${ }^{2}$ Pier Andrea Borea
}

Department of Clinical and Experimental Medicine, Pharmacology Unit, University of Ferrara, 44100 Ferrara and ${ }^{1}$ ScheringPlough Research Institute, San Raffaele Science Park, 20132 Milan, Italy

1 The present study describes the direct labelling of $\mathrm{A}_{2 \mathrm{~A}}$ adenosine receptors in human neutrophil membranes with the potent and selective antagonist radioligand, $\left[{ }^{3} \mathrm{H}\right]-5$-amino-7-(2-phenylethyl)-2-(2furyl)-pyrazolo[4,3-e]-1,2,4 triazolo[1,5-c]pyrimidine, ([ $\left.{ }^{3} \mathrm{H}\right]-\mathrm{SCH}$ 58261). In addition, both receptor affinity and potency of a number of adenosine receptor agonists and antagonists were determined in binding, adenylyl cyclase and superoxide anion production assays.

2 Saturation experiments revealed a single class of binding sites with $K_{\mathrm{d}}$ and $\mathrm{B}_{\max }$ values of $1.34 \mathrm{nM}$ and $75 \mathrm{fmol} \mathrm{mg}{ }^{-1}$ protein, respectively. Adenosine receptor ligands competed for the binding of $1 \mathrm{nM}\left[{ }^{3} \mathrm{H}\right]-$ SCH 58261 to human neutrophil membranes, with a rank order of potency consistent with that typically found for interactions with the $\mathrm{A}_{2 \mathrm{~A}}$ adenosine receptors. In the adenylyl cyclase and in the superoxide anion production assays the same compounds exhibited a rank order of potency identical to that observed in binding experiments.

3 Thermodynamic data indicated that $\left[{ }^{3} \mathrm{H}\right]-\mathrm{SCH} 58261$ binding to human neutrophils is entropy and enthalpy-driven. This finding is in agreement with the thermodynamic behaviour of antagonists binding to rat striatal $\mathrm{A}_{2 \mathrm{~A}}$ adenosine receptors.

4 It was concluded that in human neutrophil membranes, $\left[{ }^{3} \mathrm{H}\right]-\mathrm{SCH} 58261$ directly labels binding sites with pharmacological properties similar to those of $\mathrm{A}_{2 \mathrm{~A}}$ adenosine receptors of other tissues. The receptors labelled by $\left[{ }^{3} \mathrm{H}\right]-\mathrm{SCH} 58261$ mediated the effects of adenosine and adenosine receptor agonists to stimulate cyclic AMP accumulation and inhibition of superoxide anion production in human neutrophils.

Keywords: Adenosine $\mathrm{A}_{2 \mathrm{~A}}$ receptors; adenosine $\mathrm{A}_{2 \mathrm{~A}}$ receptor ligands; $\left[{ }^{3} \mathrm{H}\right]-\mathrm{SCH} 58261$ binding; human neutrophil membranes; cyclic AMP assays; superoxide anion production; thermodynamic analysis

\section{Introduction}

Adenosine acts as a neuromodulator in the central and peripheral nervous systems and as a homeostatic regulator in a variety of other tissues, including smooth muscle cells, heart muscle, platelets, coronary arteries and cells involved in immune and inflammatory reactions (Schrier \& Imre, 1986; Liang, 1992; Hussain \& Mustafa, 1993). The majority of the effects of adenosine are mediated by four pharmacologically distinct adenosine receptor subtypes, designated $A_{1}, A_{2 A}, A_{2 B}$ and $A_{3}$, all of which have been cloned and their binding profiles characterized in various cell lines (Fredholm et al., 1994; Olah \& Stiles, 1995).

Adenosine is believed to function as an endogenous antiinflammatory agent (Cronstein \& Hirschhorn, 1990) based on its ability to inhibit cellular adhesion (Cronstein et al., 1992) and superoxide anion generation (Cronstein et al., 1990). Tissue damage induced by inflammatory processes is due in part to the migration of neutrophils to the sites of inflammation (e.g. sites where there is infection, tissue injury, ischaemia or complement activation) followed by the release of membrane-damaging oxygen radicals. Adenosine inhibits both activities and therefore seems to be important in limiting abnormal and excessive inflammatory reactions. Ischaemia is a powerful stimulus for adenosine production (Rudolphi et al., 1992) and the vascular endothelium may protect itself against damage from activated neutrophils by releasing adenosine.

\footnotetext{
${ }^{2}$ Author for correspondence at: Department of Clinical and Experimental Medicine, Pharmacology Unit, University of Ferrara, via Fossato di Mortara 17-19, 44100 Ferrara, Italy.
}

Interestingly, a recent study (Bong et al., 1996) showed that the central nervous system can also influence inflammatory responses by reducing local levels of adenosine, and by in turn regulating the accumulation of neutrophils. Based on results of functional studies, it is known that $\mathrm{A}_{1}$ and at least one subtype of $\mathrm{A}_{2}$ receptors (Cronstein et al., 1985), recently proposed to be the $\mathrm{A}_{2 \mathrm{~A}}$ receptor subtype (Fredholm et al., 1996), are present on neutrophils. The activation of $A_{1}$ receptors leads to enhanced chemotactic response, whereas activation of the $A_{2}$ receptors reduces the oxidative burst. $\mathrm{A}_{2 \mathrm{~A}}$ receptors are known to activate stimulant guaninebinding proteins (Gs proteins) and thus to stimulate adenylate cyclase (Ongini \& Fredholm, 1996) but the role of adenosine $3^{\prime}: 5^{\prime}$-cyclic monophosphate (cyclic AMP) in mediating the effects of adenosine in reducing neutrophile oxidative burst is dubious (Cronstein, 1994). The lack of available radioligands that do not interact with the adenotin binding proteins (Lohse et al., 1988; Hutchinson et al., 1990) has until recently prevented the direct labelling and full pharmacological characterization of the $\mathrm{A}_{2 \mathrm{~A}}$ adenosine receptors in peripheral tissues such as human neutrophils. Recently, important progress has been made with the development of selective $\mathrm{A}_{2 \mathrm{~A}}$ receptor antagonists having an interesting pharmacological profile (Ongini \& Fredholm, 1996). One of them, the non-xanthine compound 5-amino7- (2 - phenylethyl) - 2 - (2-furyl) - pyrazolo [4,3-e]-1,2,4 - triazolo-[1,5c]-pyrimidine ( $\mathrm{SCH} 58261)$, a potent and selective $\mathrm{A}_{2 \mathrm{~A}}$ receptor antagonist (Baraldi et al., 1994), has been widely characterized in a variety of binding and functional assays (Zocchi et al., 1996a). The tritium-labelled form, $\left[{ }^{3} \mathrm{H}\right]-\mathrm{SCH}$ 
58261, has been found to label $\mathrm{A}_{2 \mathrm{~A}}$ receptors in the brain (Zocchi et al., 1996b), in peripheral tissue membranes such as porcine coronary arteries (Belardinelli et al., 1996), human platelets (Dionisotti et al., 1996), human cloned receptors transfected in mammalian cells (Dionisotti et al., 1997) and human lymphocytes (Varani et al., 1997). The present paper describes the characterization of $\mathrm{A}_{2 \mathrm{~A}}$ adenosine receptors in human neutrophils by using the selective $\mathrm{A}_{2 \mathrm{~A}}$ receptor antagonist $\left[{ }^{3} \mathrm{H}\right]-\mathrm{SCH}$ 58261. The effect of typical adenosine receptor agonists to increase the cyclic AMP intracellular levels and the potency of a series of antagonists to inhibit Nethylcarboxamidoadenosine (NECA) induced stimulation of adenylyl cyclase activity was evaluated. Moreover, the effect of adenosine receptor agonists, to inhibit superoxide anion generation, and the antagonism of the effect of increasing concentrations of 2-hexynyl-5'-N-ethylcarboxamidoadenosine (HE-NECA) on superoxide anion production by fixed concentrations of adenosine receptor antagonists in $\mathrm{N}$ formyl-L-methionyl-L-leucyl-L-phenylalanine (FMLP)-stimulated neutrophils were studied. Finally, with the aim of obtaining new insights into the forces driving the coupling of human $\mathrm{A}_{2 \mathrm{~A}}$ neutrophil receptor with a selective ligand, a thermodynamic analysis of $\left[{ }^{3} \mathrm{H}\right]-\mathrm{SCH} 58261$ binding was performed and the enthalpic $\left(\Delta \mathrm{H}^{\circ}\right)$ and entropic $\left(\Delta \mathrm{S}^{\circ}\right)$ contribution to the standard free energy $\left(\Delta \mathrm{G}^{\circ}\right)$ of the binding equilibrium were determined.

\section{Methods}

The cell preparations were isolated from heparin-treated peripheral blood $(100-200 \mathrm{ml})$ from healthy human volunteers as described below.

\section{Preparation of cell suspensions}

Human neutrophils were prepared according to the procedure of Markert et al. (1984) with modifications. Blood was supplemented with $20 \mathrm{ml}$ of a solution consisting of $6 \%$ (by weight) Dextran T500. After gentle mixing, erythrocytes were allowed to settle down at $20^{\circ} \mathrm{C}$ for $60 \mathrm{~min}$. The turbid upper layer containing leukocytes was carefully removed with polyethylene transfer pipette and placed into a $50 \mathrm{ml}$ polypropylene centrifuge tube. Leukocytes were pelleted by centrifugation at $20^{\circ} \mathrm{C}$ for $12 \mathrm{~min}$ at $100 \mathrm{~g}$. All other centrifugations were also performed in these tubes. Remaining erythrocytes were lyzed by suspending the cell pellet in $10 \mathrm{ml}$ of distilled water at $4{ }^{\circ} \mathrm{C}$ under gentle agitation. After $30 \mathrm{~s}$, isotonicity was restored by adding $3 \mathrm{ml}$ of a solution containing $0.6 \mathrm{M} \mathrm{NaCl}$. Cells were pelleted by centrifugation at $20^{\circ} \mathrm{C}$ for $5 \mathrm{~min}$ at $250 \mathrm{~g}$, suspended in $10 \mathrm{ml}$ of the Krebs Ringer phosphate buffer consisting of (mM): $\mathrm{Na}^{+} 150, \mathrm{~K}^{+} 5$, $\mathrm{Ca}^{2+} 1.3, \mathrm{Mg}^{2+} 1.2, \mathrm{Cl}^{-} 155$ and HEPES 10 at $\mathrm{pH} 7.45$ and layered onto $10 \mathrm{ml}$ of Fycoll-Hypaque. Neutrophils were sedimented by centrifugation at $20^{\circ} \mathrm{C}$ for $20 \mathrm{~min}$ at $250 \mathrm{~g}$. This procedure allowed studies of cell suspensions containing $98 \pm 2 \%$ neutrophils with few contaminating red blood cells or platelets. This cell suspension was used for measurement of cyclic AMP levels and superoxide anion production.

\section{Preparation of neutrophil membranes}

Human neutrophils were resuspended in $50 \mathrm{~mm}$ Tris $\mathrm{HCl} \mathrm{pH}$ 7.4 containing $10 \mathrm{mM} \mathrm{MgCl} 2$ and centrifuged at $11,000 \mathrm{~g}$ for $15 \mathrm{~min}$ at $4^{\circ} \mathrm{C}$. The supernatant was discarded and the pellet resuspended in $10 \mathrm{ml}$ of $50 \mathrm{~mm}$ Tris- $\mathrm{HCl}$ and centrifuged at
$11,000 \mathrm{~g}$ for $15 \mathrm{~min}$. The resulting pellet was resuspended in $50 \mathrm{~mm}$ Tris- $\mathrm{HCl}\left(\mathrm{pH} 7.4\right.$ at $\left.25^{\circ} \mathrm{C}\right)$ at a concentration of $100-$ $150 \mu \mathrm{g}$ protein $100 \mu \mathrm{l}^{-1}$ and this homogenate was used for the assay of $\left[{ }^{3} \mathrm{H}\right]-\mathrm{SCH} 58261$ binding. The protein concentration was determined according to a Bio-Rad method (Bradford, 1976) with bovine albumin as reference standard.

\section{$\left[{ }^{3} \mathrm{H}\right]-S C H 58261$ binding assay in the neutrophil membranes}

Binding assays were carried out according to Dionisotti et al. (1996). In saturation studies, neutrophil membranes were incubated with 8 to 10 different concentrations of $\left[{ }^{3} \mathrm{H}\right]-\mathrm{SCH}$ 58261 ranging from 0.05 to $10 \mathrm{nM}$ in a total volume of $250 \mu \mathrm{l}$ containing $50 \mathrm{mM}$ Tris $\mathrm{HCl}$ buffer, $10 \mathrm{mM} \mathrm{MgCl}_{2}$, $\mathrm{pH}$ 7.4. In competition experiments, carried out to determine the $\mathrm{IC}_{50}$ values, $1 \mathrm{~nm}\left[{ }^{3} \mathrm{H}\right]-\mathrm{SCH} 58261$ was incubated with $100 \mu \mathrm{l}$ of neutrophil membranes (150 $\mu \mathrm{g}$ protein/assay) and at least 8 10 different concentrations of typical adenosine agonists and antagonists. Inhibitory binding constant, $K_{\mathrm{i}}$ values were calculated from the $\mathrm{IC}_{50}$ values according to the Cheng and Prusoff equation (Cheng \& Prusoff, 1973), $K_{\mathrm{i}}=\mathrm{IC}_{50} /\left(1+\left[\mathrm{C}^{*}\right] /\right.$ $\left.K_{\mathrm{d}}^{*}\right)$, where $\left[\mathrm{C}^{*}\right]$ is the concentration of the radioligand and $K_{\mathrm{d}} *$ its dissociation constant. Non-specific binding was defined as binding in the presence of $10 \mu \mathrm{M}$ NECA and was about $40 \%$ of total binding. Incubation time was $60 \mathrm{~min}$ at $4{ }^{\circ} \mathrm{C}$ according to the results of previous time-course experiments. Bound and free radioactivity were separated by centrifugation in a Beckman microcentrifuge for $5 \mathrm{~min}$ at $12,000 \mathrm{~g}$. The pellets were washed twice without resuspension with incubation buffer and the tips of the plastic tubes were cut off, transferred into vials containing $5 \mathrm{ml}$ of Aquassure liquid scintillation and counted in a Beckman LS-1800 Spectrometer (efficiency 55\%). A weighted non linear least-squares curve fitting program LIGAND (Munson \& Rodbard, 1980), was used for computer analysis of saturation and inhibition experiments.

\section{Measurement of cyclic AMP levels in human neutrophils}

Human neutrophils $\left(10^{6}\right.$ cells $\left.\mathrm{ml}^{-1}\right)$ were suspended in $0.5 \mathrm{ml}$ incubation mixture (Krebs Ringer phosphate buffer, containing 1.0 iu adenosine deaminase $\mathrm{ml}^{-1}$ and $0.5 \mathrm{~mm}$ 4-(3-butoxy4-methoxybenzyl)-2-imidazolidinone (Ro 20-1724) as phosphodiesterase inhibitor) and preincubated for $10 \mathrm{~min}$ in a shaking bath at $37^{\circ} \mathrm{C}$. Then adenosine agonists examined plus forskolin $1 \mu \mathrm{M}$ were added to the mixture and the incubation continued for a further $5 \mathrm{~min}$. The potencies of antagonists were determined by antagonism of the NECA $(1 \mu \mathrm{M})$-induced stimulation of cyclic AMP levels. Agonist $\mathrm{EC}_{50}$ and antagonist $\mathrm{IC}_{50}$ values were obtained from concentration-response curves after log-logit transformation of dependent variables by the weighted least square method (Finney, 1978). The reaction was terminated by the addition of cold $6 \%$ trichloroacetic acid (TCA). The TCA suspension was centrifuged at 2,000 $\mathrm{g}$ for $10 \mathrm{~min}$ at $4^{\circ} \mathrm{C}$ and the supernatant was extracted four times with water-saturated diethyl ether. The final aqueous solution was tested for cyclic AMP levels by a competition protein binding assay carried out essentially according to Brown et al. (1971) and Nordstedt \& Fredholm (1990). Samples of cyclic AMP standards $(0-10 \mathrm{pmol})$ were added to each test tube containing the buffer used by Brown et al. (1971) (trizma base $0.1 \mathrm{M}$; aminophylline $8.0 \mathrm{mM} ; 2$ mercaptoethanol $6.0 \mathrm{mM}$; $\mathrm{pH}$ 7.4) and $\left[{ }^{3} \mathrm{H}\right]$-cyclic AMP in a total volume of $0.5 \mathrm{ml}$. The binding protein, previously prepared from beef adrenals, was added to the samples previously incubated at $4^{\circ} \mathrm{C}$ for $150 \mathrm{~min}$ and, after the addition of charcoal, were centrifuged at 2,000 $\mathrm{g}$ 
for $10 \mathrm{~min}$. The clear supernatant $(0.2 \mathrm{ml})$ was mixed with $4 \mathrm{ml}$ of Atomlight and counted in a LS-1800 Beckman scintillation counter.

\section{Superoxide anion production}

$\mathrm{O}_{2}{ }^{-}$release was monitored continuously with a temperaturecontrolled spectrophotometer by the reduction of ferricytochrome c inhibited by superoxide dismutase (SOD), as described elsewhere (Spisani et al., 1992). The mixture was incubated with either control or different concentrations of agonists for $5 \mathrm{~min}$ at $37^{\circ} \mathrm{C}$. At 0 time, $0.1 \mu \mathrm{M}$ FMLP was added and the amount of $\mathrm{O}_{2}{ }^{-}$produced was calculated by the differences in absorbance of the samples, with a $15.5 \mathrm{~mm}$ extinction coefficient at $550 \mathrm{~nm}$ for cytochrome c reduction. The net nanomol of $\mathrm{O}_{2}{ }^{-}$release were calculated from the formula: nanomol released by stimulated neutrophils minus nanomol released by resting neutrophils alone. Neutrophils were incubated with $5 \mu \mathrm{g} \mathrm{ml}^{-1}$ cytochalasin B for 5 min before peptide activation.

\section{Thermodynamic analysis}

For a generic binding equilibrium $\mathrm{L}+\mathrm{R}=\mathrm{LR}(\mathrm{L}=$ ligand, $\mathrm{R}=$ receptor), the affinity constant is calculated as $K_{\mathrm{A}}=[\mathrm{LR}] /$ $([\mathrm{L}] \quad[\mathrm{R}])=[\mathrm{LR}] /\left(\left[\mathrm{L}_{\max }-\mathrm{LR}\right] \quad\left[\mathrm{B}_{\max }-\mathrm{LR}\right]\right)=1 / K_{\mathrm{d}}$, where $\left[\mathrm{L}_{\max }\right]=$ total concentration of the ligand added, $\left[\mathrm{B}_{\max }\right]=$ total concentration of the binding sites and $K_{\mathrm{d}}=$ dissociation constant. As $[\mathrm{LR}] /\left[\mathrm{L}_{\max }-\mathrm{LR}\right]=[$ Bound $] /[$ Free $]=\left[\mathrm{B}_{\max }\right] \quad K_{\mathrm{A}}$ [Bound], the $K_{\mathrm{A}}$ and $\mathrm{B}_{\max }$ values can be obtained from the slope and intercept of the Scatchard plot (Scatchard, 1949) [Bound]/[Free] versus [Bound].

The standard free energy was calculated as $\Delta \mathrm{G}^{\circ}=-\mathrm{RT} \ln$ $K_{\mathrm{A}}$ at $298.15 \mathrm{~K}$, the standard enthalpy, $\Delta \mathrm{H}^{\circ}$, from the Van't Hoff plot $1 \mathrm{n} K_{\mathrm{A}}$ versus $(1 / \mathrm{T})$ (the slope of which is $-\Delta \mathrm{H}^{\circ} / \mathrm{R}$ ) and the standard entropy as $\Delta \mathrm{S}^{\circ}=\left(\Delta \mathrm{H}^{\circ}-\Delta \mathrm{G}^{\circ}\right) / \mathrm{T}$ with $\mathrm{T}=298.15 \mathrm{~K}$ and $\mathrm{R}=8.314 \mathrm{~J} \mathrm{~K}^{-1} \mathrm{~mol}^{-1}$.

Saturation experiments of $\left[{ }^{3} \mathrm{H}\right]-\mathrm{SCH} 58261$ binding to the human neutrophil membranes were carried out at $0,10,20$, $25^{\circ} \mathrm{C}$ with concentrations ranging from 0.05 to $10 \mathrm{nM}$.

\section{Drugs}

NECA (5'-N-ethylcarboxamidoadenoxine); R-PIA and S-PIA $\left(\mathbf{R}(-)\right.$ - and $\mathbf{S}(+)-\mathrm{N}^{6}$-(2-phenylisopropyl)-adenosine); CGS 21680 (2-[p-(2-carboxyethyl)-phenethylamino]-5'-N-ethylcarboxamidoadenosine); CHA ( $\mathrm{N}^{6}$-cyclohexyladenosine); CGS 15943 (5-amino-9-chloro-2-(2-furyl)1,2,4-triazolo[1,5-c]quinazoline); DPCPX (1,3-dipropyl-8-cyclopentylxanthine); XAC (8-[4-[[[ [(2-aminoethyl)amino]-carbonyl]-methyl]oxy]-phenyl]1,3-dipropylxanthine) were from Research Biochemicals Incorporated (Natick, Mass., U.S.A.). CCPA (2-chloro-N ${ }^{6}$ cyclopentyladenosine); HE-NECA (2-hexynyl-5'-N-ethylcarboxamidoadenosine); KF 17837 ((E)-1,3-dipropyl-8-(3,4dimethoxystyryl)-7-methylxanthine); SCH 58261 (5-amino-7(phenylethyl)-2-(2-furyl)-pyrazolo [4,3-e]-1,2,4,- triazolo [1,5-c] pyrimidine) were from Schering-Plough Research Institute (Milan, Italy). Ro 20-1724 (4-(3-butoxy-4-methoxybenzyl)-2imidazolidinone) was the kind gift of Dr E. Kyburz, HoffmanLa Roche (Basel, Switzerland). Dextran and Ficoll-Paque were purchased from Pharmacia (Uppsala, Sweden). FMLP (Nformyl-Lmethionyl-L-leucyl-L-phenylalanine), ferricytochrome c, cytochalasin B were from Sigma Chemicals Co. (St. Louis, MO). $\left[{ }^{3} \mathrm{H}\right]-\mathrm{SCH} 58261$ (specific activity $68.6 \mathrm{Ci} \mathrm{mmol}^{-1}$ ) was from the Schering-Plough Research Institute (Milan, Italy). $\left[{ }^{3} \mathrm{H}\right]$-cyclic AMP (specific activity $21 \mathrm{Ci} \mathrm{mmol}^{-1}$ ) was purchased from the Radiochemical Centre (Amersham, U.K.). Aquassure and Atomlight were from NEN Research Products (Boston, Mass., U.S.A.). All other reagents were of analytical grade and obtained from commercial sources.

\section{Results}

\section{$\left[{ }^{3} \mathrm{H}\right]-\mathrm{SCH} 58261$ binding assays}

Kinetic studies $(n=3)$ showed that $\left[{ }^{3} \mathrm{H}\right]-\mathrm{SCH} 58261$ binding reached equilibrium after approximately $20 \mathrm{~min}$ and was stable for at least $3 \mathrm{~h}$ (Figure 1a). $\left[{ }^{3} \mathrm{H}\right]-\mathrm{SCH} 58261$ binding was rapidly reversed by the addition of $10 \mu \mathrm{M}$ NECA (Figure 1b). Computer analysis revealed that both association and dissociation data fitted a one-component model significantly better than a two-component model $(P<0.05)$ with the following rate constants: $K_{\text {obs }}=0.09(0.05-0.11) \mathrm{min}^{-1}$ and
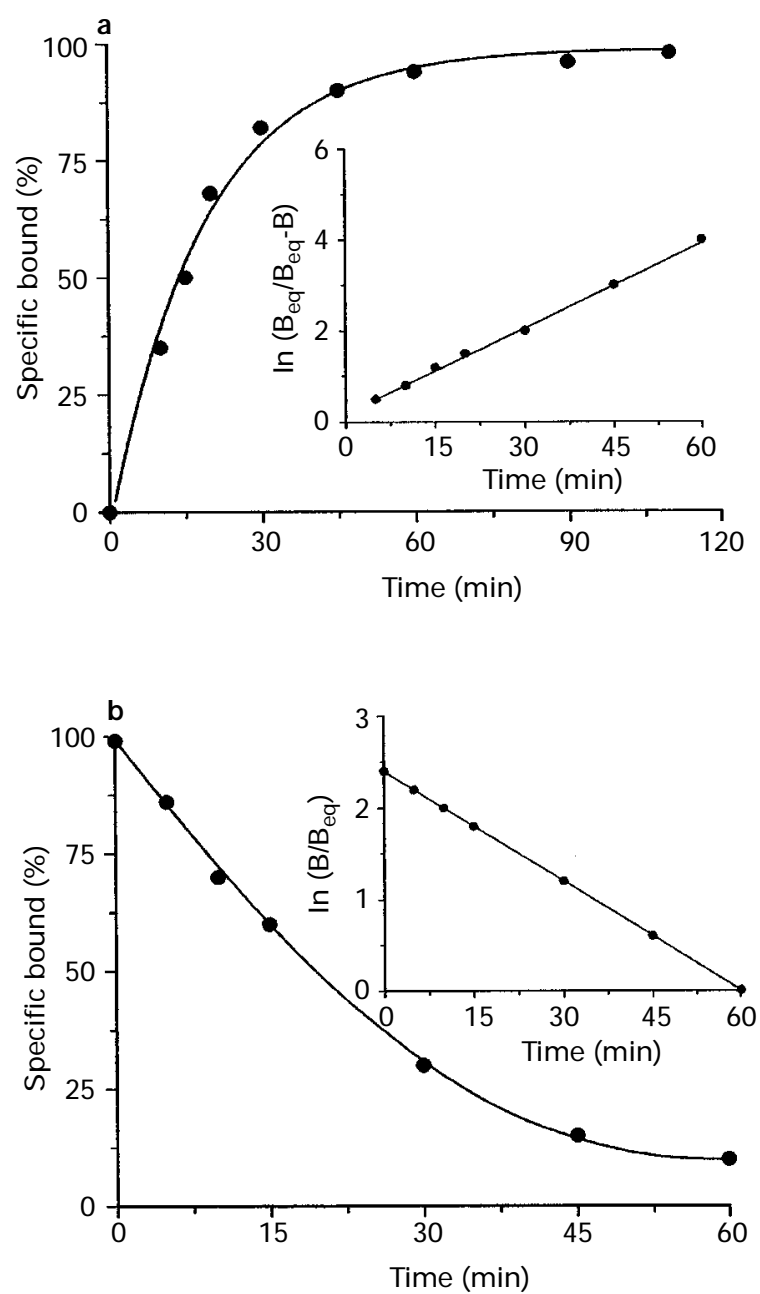

Figure 1 (a) Kinetics of $1 \mathrm{nM}\left[{ }^{3} \mathrm{H}\right]-\mathrm{SCH} 58261$ binding to human neutrophil membranes with association curves representative of a single experiment. Inset, first-order plots of $\left[{ }^{3} \mathrm{H}\right]-\mathrm{SCH} 58261$ binding. $\mathrm{B}_{\mathrm{e}}$, amount of $\left[{ }^{3} \mathrm{H}\right]-\mathrm{SCH} 58261$ bound at equilibrium; $\mathrm{B}$, amount of $\left[{ }^{3} \mathrm{H}\right]-\mathrm{SCH} 58261$ bound at each time. Association rate constant was: $K_{\text {obs }}=0.088(0.051-0.110) \mathrm{min}$. (b) Kinetics of $\left.1 \mathrm{nM} \mathrm{[}{ }^{3} \mathrm{H}\right]-\mathrm{SCH} 58261$ binding to human neturophil membranes with dissociation curves representative of a single experiment. Inset, first-order plots of $\left[{ }^{3} \mathrm{H}\right]$ $\mathrm{SCH} 58261$ binding. Dissociation rate constant was: $K_{-1}=0.046$ $(0.026-0.075) \mathrm{min}^{-1}$. The incubation time was $60 \mathrm{~min}$ at $4 \mathrm{C}$. 
$K_{-1}=0.05(0.03-0.08) \mathrm{min}^{-1}$ from a $t_{1 / 2}=15 \min (14-18)$. These values gave a kinetic dissociation constant $\left(K_{\mathrm{d}}\right)$ of 1.1 $(0.9-1.4)$ nM. Figure 2 shows a saturation curve of $\left[{ }^{3} \mathrm{H}\right]-\mathrm{SCH}$ 58261 binding to $\mathrm{A}_{2 \mathrm{~A}}$ adenosine receptors and the linearity of the Scatchard plot in the inset is indicative of the presence of a single class of binding sites with $K_{\mathrm{d}}$ value of 1.34 (1.231.48) $\mathrm{nM}$ and $\mathrm{B}_{\max }$ value of $75(70-85) \mathrm{fmol} \mathrm{mg} \mathrm{mg}^{-1}$ protein. The presence of $10 \mathrm{mM} \mathrm{MgCl}_{2}, 100 \mu \mathrm{M} \mathrm{GTP}$ or 2 iu adenosine deaminase in the assay mixture did not modify the percentage of specific binding (about 60\%). $K_{\mathrm{i}}$ values for various adenosine receptor agonists and antagonist, obtained in the competition of $\left[{ }^{3} \mathrm{H}\right]-\mathrm{SCH} 58261$ binding are summarized in Table 1. Figure $3 a$ and $b$ shows the competition curves of adenosine agonists and antagonists in human neutrophils, respectively. The rank order of potency of adenosine agonists to compete with $\left[{ }^{3} \mathrm{H}\right]-\mathrm{SCH} 58261$ binding to neutrophil membranes was: HE-NECA $>$ NECA $>$ CGS $21680>$ RPIA $>$ CCPA $>$ S-PIA $>$ CHA. HE-NECA and NECA were the most potent agonists, their affinity being in the low

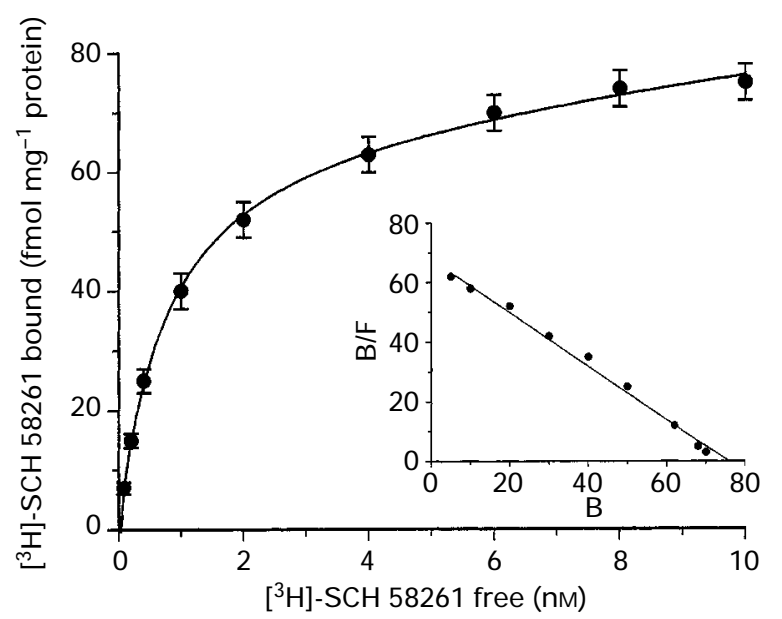

Figure 2 Saturation of $\left[{ }^{3} \mathrm{H}\right]-\mathrm{SCH} 58261$ binding to human neutrophil adenosine $A_{2 A}$ receptors. Experiments were performed as described in Methods. Values are the means and vertical lines s.e.mean of four separate experiments performed in triplicate. In the inset the Scatchard plot of the same data is shown. $K_{\mathrm{d}}$ value (nM) was $1.34(1.23-1.48)$ and $\mathrm{B}_{\max }$ value (fmol mg ${ }^{-1}$ protein) was $75(70-$ $85)$. Non-specific binding was determined in the presence of $10 \mu \mathrm{M}$ NECA. nanomolar range $(8-10 \mathrm{nM})$, while the selective $A_{1}$ receptor agonists displayed affinity values in the micromolar range. Displacement of $\left[{ }^{3} \mathrm{H}\right]-\mathrm{SCH} 58261$ binding was stereoselective, with R-PIA $\left(K_{\mathrm{i}}=990 \mathrm{nM}\right)$ being approximately 5 times more active than its stereoisomer, S-PIA $\left(K_{\mathrm{i}}=4500 \mathrm{nM}\right)$. The order of potency of the receptor antagonists was: CGS $15943>$ SCH $58261>$ XAC > KF $17837>$ DPCPX. CGS 15943 and SCH 58261 were the most potent compounds $\left(K_{\mathrm{i}}\right.$ values in the low namomolar range). Hill coefficients of most compounds (data not shown) were not significantly different from unity.

\section{Cyclic AMP assay}

Table 1 summarizes the $\mathrm{EC}_{50}$ values for forskolin-induced stimulation of cyclic AMP levels in human neutrophils and Figure $4 \mathrm{a}$ shows the log dose-response curve for typical adenosine receptor agonists. All adenosine analogues were able to increase cyclic AMP levels displaying an order of potency identical to that observed in binding affinities for the adenosine $\mathrm{A}_{2 \mathrm{~A}}$ receptor. HE-NECA appeared to be the most potent compound $\left(\mathrm{EC}_{50}=30 \mathrm{nM}\right)$ followed by NECA and CGS 21680 ( $\mathrm{EC}_{50}$ in the range $150-400 \mathrm{nM}$ ); R-PIA was more potent than its stereoisomer S-PIA $\left(\mathrm{EC}_{50}=3 \mu \mathrm{M}\right.$ and $9 \mu \mathrm{M}$, respectively). Figure $4 \mathrm{~b}$ shows the inhibition of cyclic AMP accumulation in human neutrophils by adenosine receptor antagonists and Table 1 summarizes the $\mathrm{IC}_{50}$ values of the same compounds. The most potent adenosine receptor antagonists were CGS 15943 and SCH 58261 ( IC $_{50}=15$ and $20 \mathrm{nM}$, respectively). The Spearman's rank correlation coefficient between affinity values of $\left[{ }^{3} \mathrm{H}\right]-\mathrm{SCH} 58261$ binding to $\mathrm{A}_{2 \mathrm{~A}}$ adenosine receptor by selected receptor agonists and antagonists and the $\mathrm{EC}_{50}$ and $\mathrm{IC}_{50}$ values in the cyclic AMP assay was $1.00(P<0.01)($ Table 2). A comparison of the $K_{\mathrm{i}}, \mathrm{EC}_{50}$ and $\mathrm{IC}_{50}$ values indicated that a high correlation exists between data obtained from binding and cyclic AMP assays (Figure 6a).

\section{Effects of adenosine agonists and antagonists on generation of superoxide anion by FMLP-stimulated neutrophils}

We compared the ability of adenosine agonists to inhibit the generation of superoxide anion by neutrophils incubated in the presence of the metabolite cytochalasine B. All compounds inhibited superoxide anion generation stimulated by FMLP in

Table 1 Inhibition of $\left[{ }^{3} \mathrm{H}\right]-\mathrm{SCH} 58261$ binding $\left(K_{\mathrm{i}}\right)$ by adenosine agonists and antagonists to human neutrophil membranes

\begin{tabular}{|c|c|c|c|}
\hline Compound & $\begin{array}{c}\left.{ }^{3} H\right]-S C H \quad 58261 \\
\text { binding } \mathrm{K}_{i}(\mathrm{nM})\end{array}$ & $\begin{array}{l}\text { Cyclic } A M P \text { assay } \\
E C_{50} \text { and } I C_{50}(\mathrm{nM})\end{array}$ & $\begin{array}{c}\mathrm{O}_{2}{ }^{-} \text {production } \\
E_{50}(\mathrm{nM})\end{array}$ \\
\hline $\begin{array}{l}\text { Agonists } \\
\text { HE-NECA } \\
\text { NECA } \\
\text { CGS } 21680 \\
\text { R-PIA } \\
\text { CCPA } \\
\text { S-PIA } \\
\text { CHA }\end{array}$ & $\begin{array}{rr}7.66 & (7.44-7.90) \\
9.84 & (8.01-12.08) \\
200 & (184-216) \\
990 & (841-1165) \\
1980 & (1683-2329) \\
4486 & (4102-4905) \\
6199 & (5366-7161)\end{array}$ & $\begin{array}{rr}30 & (25-35) \\
150 & (127-177) \\
400 & (371-430) \\
3000 & (2693-3339) \\
7000 & (6380-7680) \\
9000 & (8502-9528) \\
11000 & (10226-11838)\end{array}$ & $\begin{array}{rr}3.0 & (2.5-3.6) \\
30.0 & (24.6-35.9) \\
300 & (278-323) \\
998 & (890-1116) \\
1995 & (1779-2233) \\
3997 & (3777-4230) \\
14978 & (13888-16153)\end{array}$ \\
\hline $\begin{array}{l}\text { Antagonists } \\
\text { CGS } 15943 \\
\text { SCH } 58261 \\
\text { XAC } \\
\text { KF 17837 } \\
\text { DPCPX }\end{array}$ & $\begin{array}{rr}0.15 & (0.11-0.19) \\
1.38 & (1.25-1.51) \\
8.71 & (7.76-9.77) \\
22 & (19-24) \\
274 & (255-295)\end{array}$ & $\begin{array}{r}(15-16) \\
(18-22) \\
(56-64) \\
(71-91) \\
(459-544)\end{array}$ & $\begin{array}{l}- \\
- \\
- \\
- \\
-\end{array}$ \\
\hline
\end{tabular}

A comparison is made with stimulation and inhibition of NECA ( $1 \mu \mathrm{M})$ stimulated cyclic AMP levels by agonists (EC 50$)$ and antagonists $\left(\mathrm{IC}_{50}\right)$ and with inhibition of $\mathrm{O}_{2}^{-}$production by adenosine agonists $\left(\mathrm{EC}_{50}\right)$ in human isolated neutrophils. Each value is the geometric mean (with 95\% confidence limits in parentheses) of at least four separate experiments performed in duplicate. 
a dose-dependent manner (Figure 5a). The rank order of relative potency (concentration required for half-maximal response, $\mathrm{EC}_{50}(95 \%$ confidence interval $\left.) \mathrm{nM}\right)$ was: HE-NECA (3.0 (2.5-3.6)) > NECA $(30.0(24.6-35.9)>$ CGS 21680 $(300(278-323))>$ R-PIA $(998(890-1116))>$ CCPA $(1995$ $(1779-2233))>$ S-PIA $(3997$ (3777-4230)) $>$ CHA $(14978$ (13888-16153)). HE-NECA was a significantly more potent
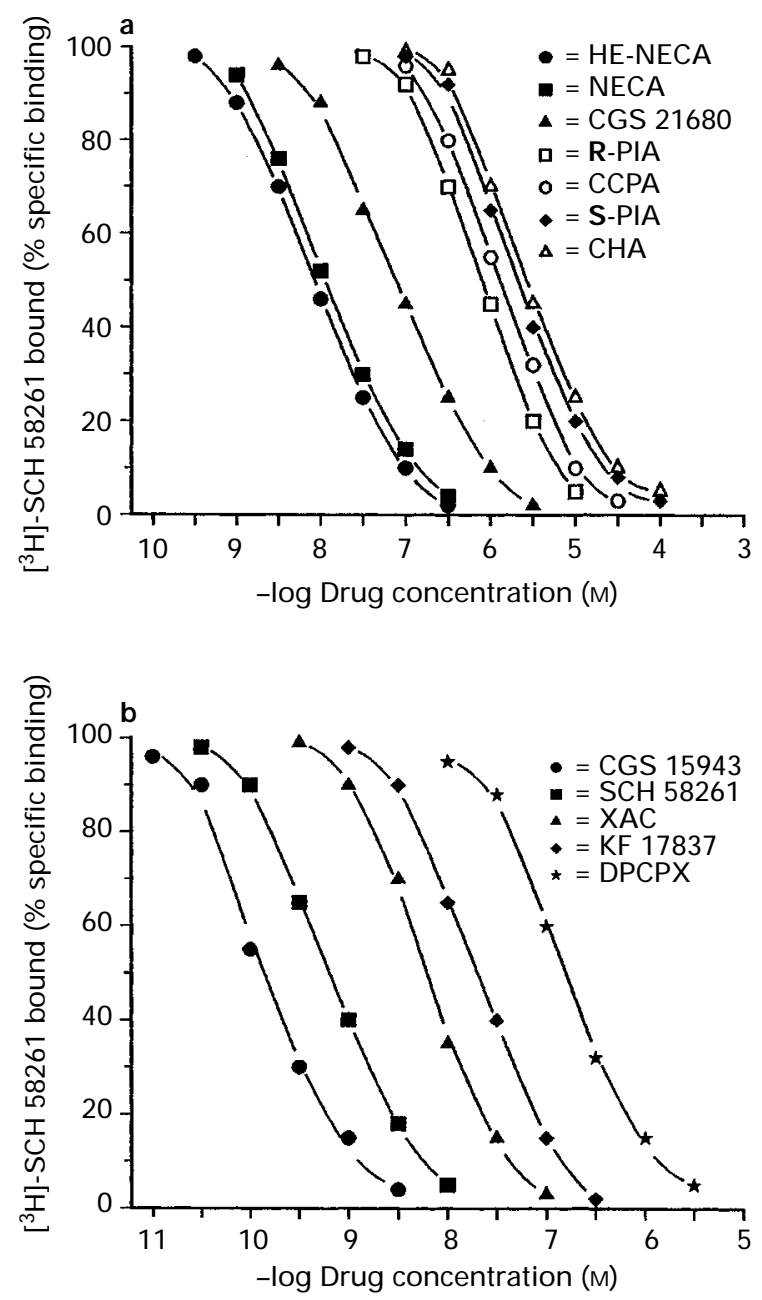

Figure 3 (a) Competition curves of specific $\left[{ }^{3} \mathrm{H}\right]-\mathrm{SCH} 58261$ (1 nM) binding to human neutrophil membranes by adenosine agonists. Curves are representative of a single experiment from a series of four independent experiments. Non-specific binding was determined in the presence of $10 \mu \mathrm{M}$ NECA. (b) Competition curves of specific $\left[{ }^{3} \mathrm{H}\right]-$ SCH 58261 (1 nM) binding to human neutrophil membranes by adenosine antagonists. Mean values of four experiments performed in duplicate are shown. Curves are representative of a single experiment from a series of four independent experiments. Non-specific binding was determined in the presence of $10 \mu \mathrm{m}$ NECA. inhibitor of superoxide anion generation than NECA or CGS 21680. To characterize further the mechanism involved we used a series of antagonists. The adenosine $\mathrm{A}_{1}$ receptorselective antagonist DPCPX, at a concentration of $100 \mathrm{nM}$ did not antagonize the effect of HE-NECA. In contrast, SCH $58261(100 \mathrm{nM})$ and CGS $15943(100 \mathrm{nM})$ fully antagonized HE-NECA whereas XAC and KF 17837 had an intermediate
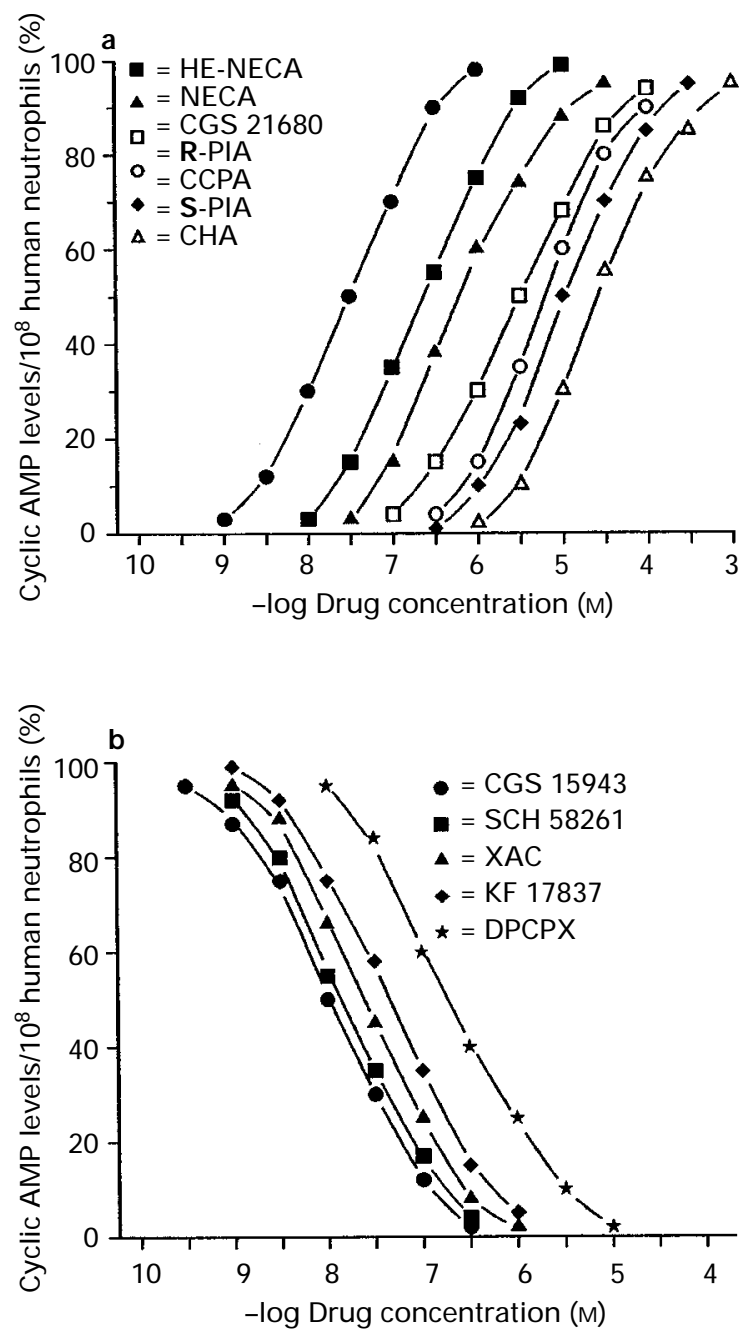

Figure 4 (a) Stimulation of cyclic AMP levels in human neutrophils by adenosine agonists. Curves are representative of a single experiment from a series of four independent experiments. (b) Inhibition of NECA $(1 \mu \mathrm{M})$ stimulated cyclic AMP levels $(100 \%)$ in human neutrophils by adenosine antagonists. Curves are representative of a single experiment from a series of four independent experiments.

Table 2 Correlation between affinity values of tested agonists and antagonists in the $\left[{ }^{3} \mathrm{H}\right]-\mathrm{SCH} 58261$ binding assay to human neutrophil membranes and corresponding $K_{\mathrm{i}}$ values, $\mathrm{EC}_{50}$ and $\mathrm{IC}_{50}$ values

$\begin{array}{lcccc}\text { Affinity data } & \mathrm{n} & \begin{array}{c}\text { Spearman rank order } \\ \text { correlation coefficient }\end{array} & \begin{array}{c}\text { Probability } \\ \text { (one-tailed test) }\end{array} & \begin{array}{c}\text { References } \\ K_{\mathrm{i}} \text { rat striatal membranes }\end{array} \\ K_{\mathrm{i}} \text { human platelet membranes } & 11 & 0.98 & <0.01 & \text { Zocchi } \text { et al. } \text { (1996b) } \\ K_{\mathrm{i}} \text { human lymphocyte membranes } & 12 & 0.97 & <0.01 & \text { Dionisotti } \text { et al. }(1996) \\ K_{\mathrm{i}} \mathrm{CHO} \text { cells } & 12 & 0.98 & <0.01 & \text { Varani } \text { et al. }(1997) \\ \mathrm{EC}_{50} \text { and IC } \mathrm{IC}_{50} \text { (cyclic AMP) } & 11 & 0.97 & <0.01 & \text { Dionisotti } \text { et al. }(1997) \\ \mathrm{EC}_{50}\left(\mathrm{O}_{2}-\text { release) }\right. & 12 & 1.00 & <0.01 & \text { Present study } \\ & 7 & 1.00 & <0.01 & \text { Present study }\end{array}$

The $K_{\mathrm{i}}$ values were obtained in rat striatum, human platelets, human lymphocytes, CHO cells transfected with the human $\mathrm{A}_{2 \mathrm{~A}}$ receptor, $\mathrm{EC}_{50}$ and $\mathrm{IC}_{50}$ values in the cyclic AMP assay, $\mathrm{EC}_{50}$ in the superoxide anion production. 
potency (Figure 5b). The rank order of potency of the antagonists to inhibit the effect of HE-NECA in neutrophils was: CGS $15943(99.7(89.0-111.6))>$ SCH $58261(78.2$ $(75.2-82.7))>\mathrm{XAC}(15.0(13.9-16.2))>\mathrm{KF} 17837(11.0$ $(10.4-11.6))>$ DPCPX (3.2 (3.0 - 3.4)). The Spearman's rank correlation coefficient between affinity values of $\left[{ }^{3} \mathrm{H}\right]-\mathrm{SCH}$ 58261 binding to $\mathrm{A}_{2 \mathrm{~A}}$ adenosine receptor by selected receptor agonists and antagonists and the $\mathrm{EC}_{50}$ and $\mathrm{IC}_{50}$ values in superoxide anion production assay was $1.00(P<0.01)$ (Table $2)$. The comparison of $K_{\mathrm{i}}, \mathrm{EC}_{50}$ and $\mathrm{IC}_{50}$ values indicated that a high correlation exists between data obtained from binding and $\mathrm{O}_{2}{ }^{-}$release (Figure $6 \mathrm{~b}$ ).

\section{Thermodynamic binding assay}

$K_{\mathrm{d}}$ and $\mathrm{B}_{\max }$ values derived from the saturation experiments of $\left[{ }^{3} \mathrm{H}\right]-\mathrm{SCH} 58261$ binding to $\mathrm{A}_{2 \mathrm{~A}}$ adenosine receptors performed at the four temperatures selected were found within the following range: $K_{\mathrm{d}}=1.34-5.50 \mathrm{nM}$ and $\mathrm{B}_{\max }=75-80 \mathrm{fmol} \mathrm{mg}^{-1}$ protein. While dissociation constants $\left(K_{\mathrm{d}}\right)$ changed with temperature, $\mathrm{B}_{\max }$ values obtained from $\left[{ }^{3} \mathrm{H}\right]-\mathrm{SCH} 58261$ saturation experiments appeared to be largely independent of it. Scatchard plots were linear at all temperatures investigated
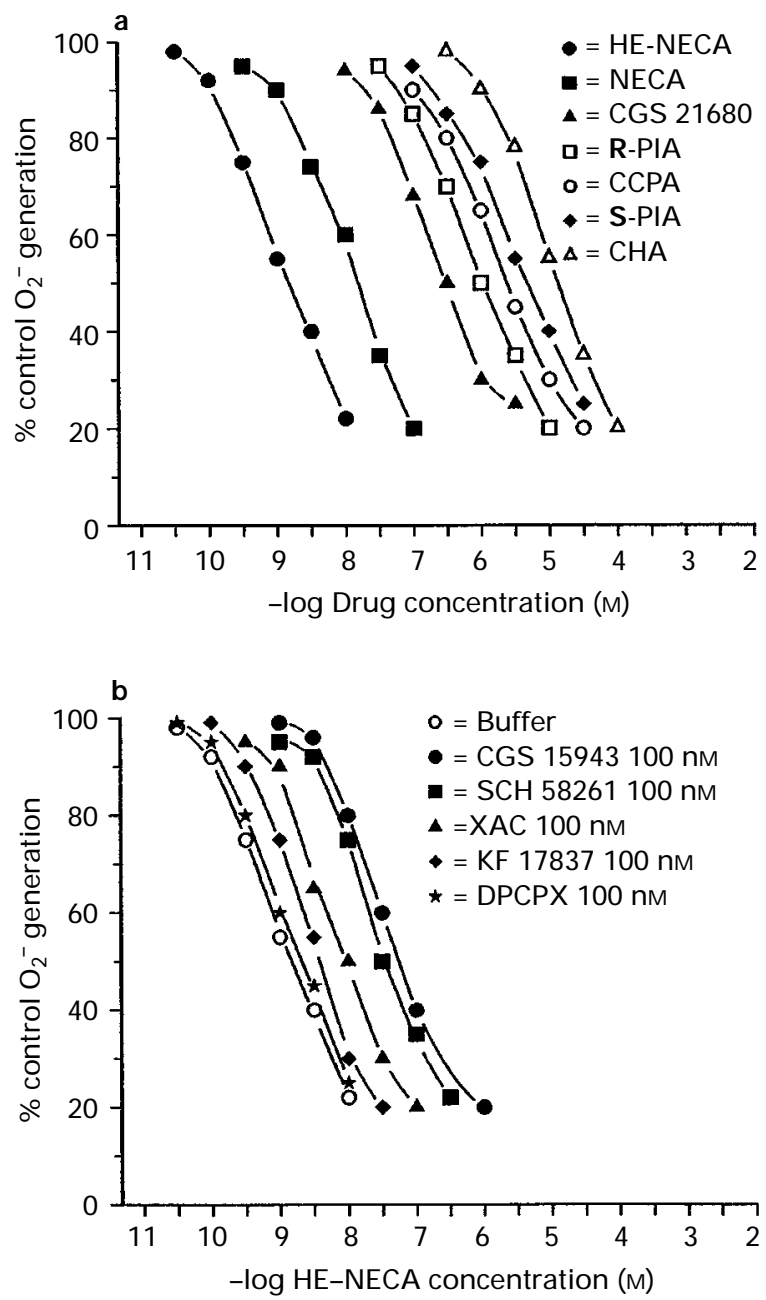

Figure 5 (a) Effect of adenosine receptor agonists on $\mathrm{O}_{2}{ }^{-}$ production induced by FMLP in human neutrophils. Curves are representative of a single experiment from a series of four independent experiments. (b) Antagonism of the effect of increasing concentrations of HE-NECA on $\mathrm{O}_{2}{ }^{-}$production induced by FMLP in human neutrophils. Curves are representative of a single experiment from a series of four independent experiments. and computer analysis of the data (Munson \& Rodbard, 1980) failed to show a significantly better fit to a two-site than to a one-site binding model, indicating that only one class of binding sites was present under our experimental conditions.
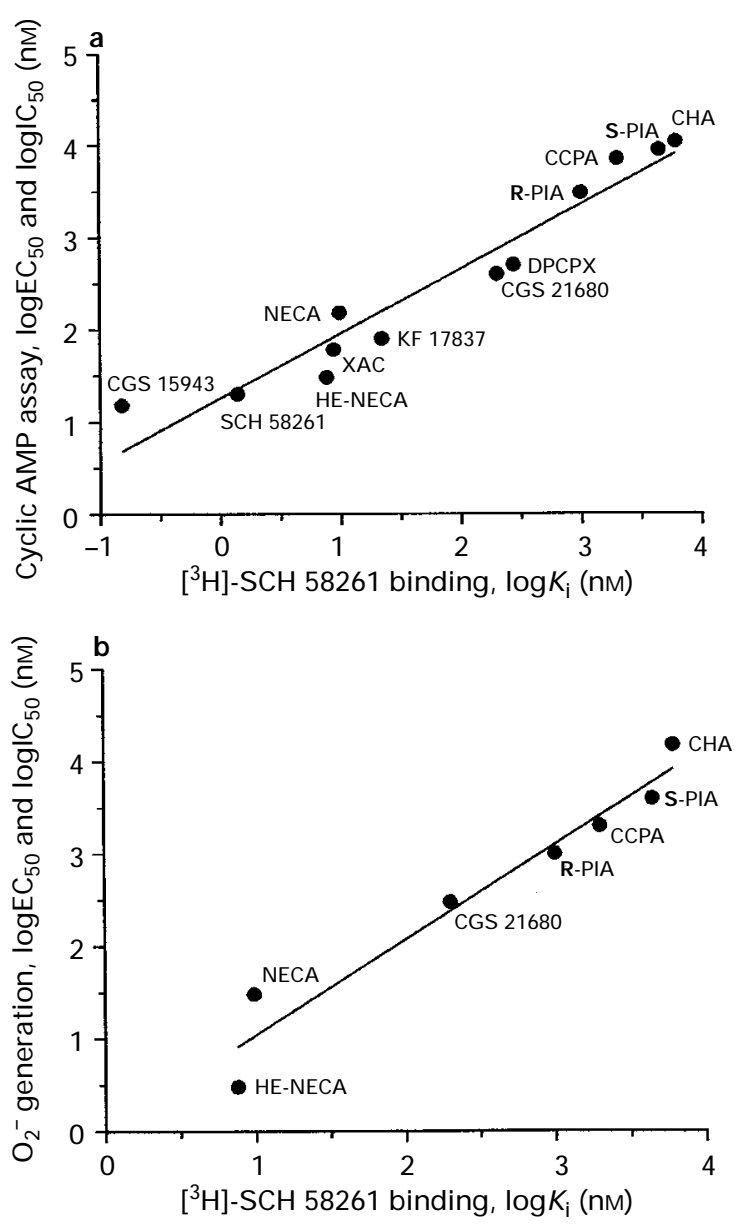

Figure 6 (a) Comparison between stimulation/inhibition of cyclic AMP levels and $\left[{ }^{3} \mathrm{H}\right]-\mathrm{SCH} 58261$ binding at $\mathrm{A}_{2 \mathrm{~A}}$ adenosine receptors in human neutrophils $(r=0.99 ; P<0.01)$. (b) Comparison between inhibition by agonists of $\mathrm{O}_{2}{ }^{-}$production induced by FMLP and $\left[{ }^{3} \mathrm{H}\right]-\mathrm{SCH} 58261$ binding at $\mathrm{A}_{2 \mathrm{~A}}$ adenosine receptors in human neutrophils $(r=1.00 ; P<0.01)$.

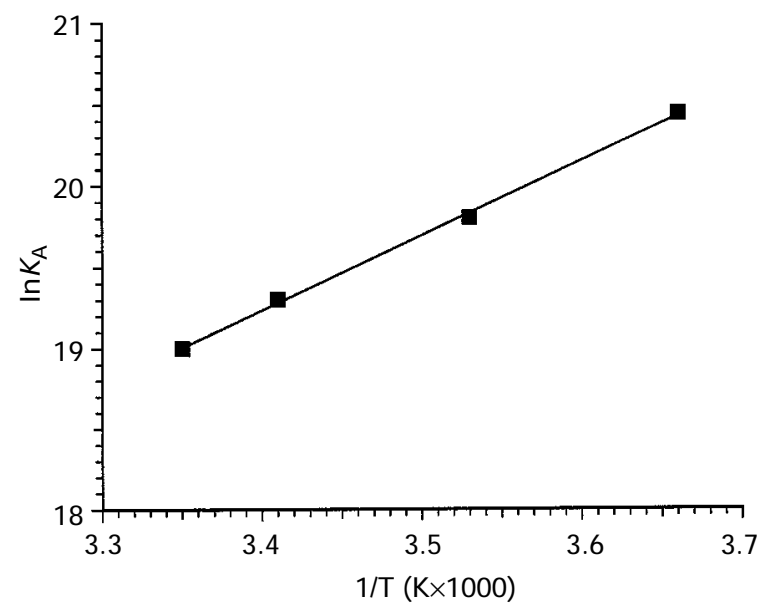

Figure 7 Van't Hoff plot showing the effect of temperature on the equilibrium binding association constant, $K_{\mathrm{A}}=1 / K_{\mathrm{d}}$, of $\left[{ }^{3} \mathrm{H}\right]-\mathrm{SCH}$ 58261. The plot is essentially linear in the temperature range investigated $\left(0-25^{\circ} \mathrm{C}\right)$. 
Figure 7 presents the van't Hoff plot $1 \mathrm{n} K_{\mathrm{A}}$ versus $1 / \mathrm{T}$ of the $\left[{ }^{3} \mathrm{H}\right]-\mathrm{SCH} 58261$ binding to the $\mathrm{A}_{2 \mathrm{~A}}$ adenosine receptor and the final equilibrium thermodynamic parameters (expressed as means values \pm s.e. of three independent determinations) were: $\Delta \mathrm{G}^{\circ}=-47.07 \pm 0.12 \mathrm{~kJ} \mathrm{~mol}^{-1} ; \Delta \mathrm{H}^{\circ}=-35.67 \pm 3.38 \mathrm{~kJ}$ $\mathrm{mol}^{-1} ; \Delta \mathrm{S}^{\circ}=38.46 \pm 3.52 \mathrm{~J} \mathrm{~mol}^{-1} \mathrm{~K}^{-1}$. The linearity of the plot was statistically significant $\left(\Delta \mathrm{Cp}^{\circ} \approx 0\right)$ and its slope $\left(-\Delta \mathrm{H}^{\circ} / \mathrm{R}\right)$ was positive, a property which has been found to be typical for antagonist binding to rat striatal $\mathrm{A}_{2 \mathrm{~A}}$ adenosine receptors (Borea et al., 1995).

\section{Discussion}

The newly developed $\mathrm{A}_{2 \mathrm{~A}}$ adenosine receptor antagonist radioligand, $\left[{ }^{3} \mathrm{H}\right]-\mathrm{SCH}$ 58261, which has been recently shown to display negligible affinity for the adenotin sites (Varani et al., 1996) and to label $\mathrm{A}_{2 \mathrm{~A}}$ adenosine receptors in a variety of tissues including human platelets (Dionisotti et al., 1996) and human lymphocytes (Varani et al., 1997), represents a key advance towards the characterization of $\mathrm{A}_{2 \mathrm{~A}}$ adenosine receptors.

In the present study we characterized the $A_{2 A}$ adenosine receptor on human neutrophil membranes by using $\left[{ }^{3} \mathrm{H}\right]-\mathrm{SCH}$ 58261. Association and dissociation kinetic parameters of $\left[{ }^{3} \mathrm{H}\right]-$ SCH 58261 binding were similar to those observed in a previous study carried out in human platelets (Dionisotti et al., 1996), and human lymphocytes (Varani et al., 1997). In saturation experiments $\left[{ }^{3} \mathrm{H}\right]-\mathrm{SCH} 58261$ labelled a single class of recognition sites with affinity $\left(K_{\mathrm{d}}=1.3 \mathrm{nM}\right)$ in the same order of magnitude as that determined by kinetic experiments $\left(K_{\mathrm{d}}=1.1 \mathrm{nM}\right)$ and also similar to that observed in rat striatal and platelet membranes $\left(K_{\mathrm{d}}=0.7 \mathrm{nM}\right.$ and $0.8 \mathrm{nM}$, respectively). In competition binding studies, various adenosine receptor agonists and antagonists bound the $A_{2 \mathrm{~A}}$ neutrophil receptor with a rank order of potency and affinity range similar to that observed for $\left[{ }^{3} \mathrm{H}\right]-\mathrm{SCH} 58261$ binding to human platelet membranes. Computer analysis of competition curves of both adenosine agonists and antagonists showed that $\left[{ }^{3} \mathrm{H}\right]-\mathrm{SCH}$ 58261 interacted with only one recognition binding site (Hill coefficients not significantly different from unity). This is in agreement with previous data by Zocchi et al. (1996b).

Our data are also in agreement with those previously obtained in rat striatal, human platelet and lymphocyte membranes and $\mathrm{CHO}$ cells transfected with the human cloned $\mathrm{A}_{2 \mathrm{~A}}$ receptor. It is worth noting that contrasting results have been obtained in the literature about the effect of $\mathrm{A}_{2 \mathrm{~A}}$ adenosine receptor antagonists to reveal both high and low affinity state (Bruns et al., 1987; Nonaka et al., 1994). However, our data are in agreement with those obtained with $\left[{ }^{3} \mathrm{H}\right]-\mathrm{SCH} 58261$ (Zocchi et al., 1996b; Belardinelli et al., 1996) in striatal and coronary artery membranes and $\left[{ }^{3} \mathrm{H}\right]-\mathrm{PD}$ 115,199 (Bruns et al., 1987), which displaced $\mathrm{A}_{2 \mathrm{~A}}$ striatal receptors with Hill coefficients close to unity excluding the involvement of multiple coupling affinity states. This finding could be explained either by a tight coupling between receptor and $\mathrm{G}$ protein or, alternatively by the existence of a uniform conformation of the receptor binding subunit regardless of $G$ protein modulation (Nanoff et al., 1991 Nanoff \& Stiles, 1993).

Thermodynamic analysis of $\left[{ }^{3} \mathrm{H}\right]-\mathrm{SCH} 58261$ binding was performed and the enthalpic $\left(\Delta \mathrm{H}^{\circ}\right)$ and entropic $\left(\Delta \mathrm{S}^{\circ}\right)$ contribution to the standard free energy $\left(\Delta \mathrm{G}^{\circ}\right)$ of the binding equilibrium were determined. The linearity of the van't Hoff plot for $\left[{ }^{3} \mathrm{H}\right]-\mathrm{SCH} 58261$ binding in the human neutrophils indicates that the $\Delta \mathrm{Cp}^{\circ}$ values of the drug-interaction is nearly zero, which means that $\Delta \mathrm{H}^{\circ}$ and $\Delta \mathrm{S}^{\circ}$ values are not significantly affected by temperature variations at least over the temperature range investigated (Borea et al., 1995). The linearity of van't Hoff plots in a limited range of temperatures (usually $0-25 / 30^{\circ} \mathrm{C}$ ) appears to be a common feature of practically all membrane receptor ligands so far studied from a thermodynamic point of view (Gilli et al., 1994). Thermodynamic data obtained from the van't Hoff plot, indicate that $\left[{ }^{3} \mathrm{H}\right]-\mathrm{SCH} 58261$ binding to human neutrophils is entropy and enthalpy-driven $\quad\left(\Delta \mathrm{S}^{\circ}=38.46 \pm 3.52 \quad \mathrm{~J} \mathrm{~mol}^{-1} \mathrm{~K}^{-1}, \quad \Delta \mathrm{H}^{\circ}=\right.$ $-35.67 \pm 3.38 \mathrm{~kJ} \mathrm{~mol}^{-1}$ ). This binding behaviour has been found, in rat striatum, to be typical of $\mathrm{A}_{2 \mathrm{~A}}$ receptor antagonists (Borea et al., 1995).

Another aim of the present study was to investigate the regulation of adenylate cyclase activity to determine whether the binding parameters correlated with the functional response. We determined the $\mathrm{EC}_{50}$ and $\mathrm{IC}_{50}$ values obtained for either stimulation or inhibition of cyclic AMP levels, by receptor agonists and antagonists, respectively. Interestingly, in the adenylate cyclase assay, the compounds studied exhibited a rank order of potency similar to that observed in binding experiments. For example, HE-NECA and NECA, adenosine receptor agonists known to have the highest affinity for human platelets, lymphocytes and neutrophils, were also the most potent compounds in the cyclic AMP assay. Additionally, CGS 21680, an agonist considered potent and highly selective for $\mathrm{A}_{2 \mathrm{~A}}$ receptors, was found to have an affinity and potency similar to that of DPCPX, a potent and selective $\mathrm{A}_{1}$ adenosine receptor antagonist. This finding cannot be easily explained. Nevertheless, it shows that DPCPX at concentrations $>100 \mathrm{nM}$ is not selective for $\mathrm{A}_{1}$ receptors, and that CGS 21680 has low affinity for $A_{2 A}$ receptors in neutrophils. In addition, in a recent study, Lindström et al. (1996) provided evidence that CGS 21680 binds not only to classical $\mathrm{A}_{2 \mathrm{~A}}$ receptors, but also to sites that differ from defined adenosine receptors. CGS 21680 was 20 fold less potent than NECA, and this is in good agreement with that found in human platelets (Dionisotti et al., 1996) and lymphocytes (Varani et al., 1997). Altogether these findings indicate that HE-NECA, because of its high affinity, is perhaps more suitable than CGS 21680 to be used as standard agonist for identifying $\mathrm{A}_{2 \mathrm{~A}}$ receptors. Likewise, adenosine receptor antagonists CGS 15943 and SCH 58261 are potent in binding $\left(K_{\mathrm{i}}=0.1 \mathrm{nM}\right.$ and $1.4 \mathrm{nM}$, respectively) and functional assays $\left(\mathrm{IC}_{50}=15 \mathrm{nM}\right.$ and $20 \mathrm{nM}$ ), as observed in a variety of cell membranes (Ongini \& Fredholm, 1996). Thus, like $A_{2}$ receptors in other mammalian tissues, those present on neutrophils are coupled with adenylate cyclase

Table 3 Correlation between $\mathrm{EC}_{50}$ and $\mathrm{IC}_{50}$ values of adenosine receptor agonists and antagonists, respectively, obtained in cyclic AMP assays with human neutrophils, platelets, lympocytes and $\mathrm{CHO}$ cells transfected with the human $\mathrm{A}_{2 \mathrm{~A}}$ receptor

\begin{tabular}{|c|c|c|c|c|}
\hline & $\mathrm{n}$ & $\begin{array}{l}\text { Spearman rank order } \\
\text { correlation coefficient }\end{array}$ & $\begin{array}{c}\text { Probability } \\
\text { (one-tailed test) }\end{array}$ & References \\
\hline Human platelets & 12 & 1.00 & $<0.01$ & Varani et al. (1996) \\
\hline Human lymphocytes & 12 & 1.00 & $<0.01$ & Varani et al. (1997) \\
\hline CHO cells & 9 & 0.82 & $<0.01$ & Dionisotti et al. (1997) \\
\hline
\end{tabular}


stimulation. Our studies of inhibition of superoxide anion generation by adenosine analogues indicate that the receptor on neutrophils is of the $A_{2 A}$ subtype. Adenosine analogues were similar in both their ability to inhibit superoxide anion generation and their ability to inhibit the binding of $\left[{ }^{3} \mathrm{H}\right]-\mathrm{SCH}$ 58261. Thus, the rank order of potency of the agonists to inhibit superoxide anion generation was HE-NECA $>$ NECA $>$ CGS $21680>$ R-PIA $>$ CCPA $>$ S-PIA $>$ CHA, a finding that is in perfect agreement with the affinities obtained in the binding assays. Similarly, the data on antagonists of HE-NECA actions in human neutrophils are in reasonable agreement with those obtained in the binding assay. Moreover a good correlation was found between cyclic AMP accumulation data and inhibition of $\mathrm{O}_{2}{ }^{-}$generation by adenosine receptor agonists used in the present study (Spearman rank correlation coefficient $=1.00$, $P<0.01)$. This finding suggests that cyclic AMP could be involved in the action of $\mathrm{A}_{2 \mathrm{~A}}$ receptors to inhibit superoxide anion formation. The finding that the potencies of adenosine receptor agonists and antagonists obtained in the binding assays were greater than the potencies of the same receptor agonists and antagonists obtained in the cyclic AMP and $\mathrm{O}_{2}{ }^{-}$ production assays is probably due to the different temperatures used in the experiments. However, it is worth noting that the rank order of potencies of the receptor agonists and antagonists obtained in the binding assays were identical to that obtained in the functional assays (cyclic AMP and superoxide anion production).

Finally, we calculated the Spearman's rank correlation coefficient between receptor affinity values of $\left[{ }^{3} \mathrm{H}\right]-\mathrm{SCH} 58261$ binding to human neutrophils $\mathrm{A}_{2 \mathrm{~A}}$ receptors and $K_{\mathrm{i}}$ values of selected agaonists and antagonists obtained in different membrane preparations, such as rat striatal, human platelet and lymphocyte membranes, $\mathrm{CHO}$ cells transfected with the human $\mathrm{A}_{2 \mathrm{~A}}$ receptors. It is worth noting that the correlation coefficients were highly statistically significant, suggesting that $\mathrm{A}_{2 \mathrm{~A}}$ receptors are similar in all preparations described above, and also reasonably good agreement was found between binding results and functional data in human lymphocytes for adenosine receptor ligands (Table 2). Likewise, we also calculated the Spearman's rank correlation coefficient between $\mathrm{EC}_{50}$ and $\mathrm{IC}_{50}$ values in the cyclic AMP assay of the adenosine ligands examined leading us to conclude that, as far as the effector system is concerned, no relevant differences in the signal transmission pathways were found (Table 3). Regression analysis between $\mathrm{A}_{2 \mathrm{~A}}$ receptor binding affinities and pharmacological acitivty data on neutrophils showed a significant positive correlation (Figure 6b). Altogether, these data indicate that the adenosine receptors present in human neutrophil membranes are of the $A_{2 A}$ subtype. This conclusion is consistent with the RT-PCR study carried out by Fredholm et al. (1996) on human neutrophils.

Neutrophils are the most abundant circulating white blood cells and are usually the first cells to respond to infectious or inflammatory stimuli. Like monocytes, neutrophils can phagocytose appropriately opsonized bacteria (coated with either specific antibodies or complement components) or other particulate matter. Upon stimulation, these cells may also secrete potentially toxic oxygen metabolites (Zhang \& Fredholm, 1994) and lysosomal enzymes into the supernatant medium. When stimulated, these cells reach extravascular foci of infection or inflammation by adhering to vascular endothelium and migrating towards the source of the chemoattractants. Adenosine itself or compounds which stimulate $\mathrm{A}_{2}$ receptors selectively inhibit neutrophil adhesion to endothelium, $\mathrm{O}_{2}{ }^{-}$generation and inhibit phagocytosis of immunoglobulin-coated red blood cells (Cronstein et al., 1990). Thus, the $A_{2 A}$ receptor can be involved in modulating the biological activities of neutrophils.

In conclusion, the results of our experiments indicate that human neutrophils have an $\mathrm{A}_{2 \mathrm{~A}}$ adenosine receptor with a pharmacological, biochemical and thermodynamic profile typical of the $A_{2 A}$ receptor subtype of other cell types. Because the products released by activated neutrophils are implicated in a variety of inflammatory disorders, selective $\mathrm{A}_{2 \mathrm{~A}}$ receptor ligands may prove to be useful pharmacological tools to investigate inflammatory mechanisms. The presence of $\mathrm{A}_{2 \mathrm{~A}}$ receptors associated with the functional response of human neutrophils is also strongly supportive of an important role for adenosine in modulating inflammatory responses in a variety of pathophysiological events.

P.A.B. was supported by MURST $60 \%$.

\section{References}

BARALDI, P.G., MANFREDINI, S., SIMONI, D., ZAPPATERRA, L. ZOCCHI, C., DIONISOTTI, S. \& ONGINI, E. (1994). Synthesis of new pyrazolo[4,3-e]1,2,4-triazolo[1,5-c]pyrimidine and 1,2,3triazolo[1,5-c]pyrimidine displaying potent and selective activity as $\mathrm{A}_{2 \mathrm{~A}}$ adenosine receptor antagonists. Bioorg. Med. Chem. Lett., 4, $2539-2544$

BELARDINELLI, L., SHRYOCK, J.C., RUBLE, J., MONOPOLI, A., DIONISOTTI, S., ONGINI, E., DENNIS, D.M. \& BAKER, S.P. (1996). Binding of the novel non-xanthine $\mathrm{A}_{2 \mathrm{~A}}$ adenosine receptor antagonist $\left[{ }^{3} \mathrm{H}\right]-\mathrm{SCH} 58261$ to coronary artery membranes. Circ. Res., 79, $1153-1160$.

BONG, G.W., ROSENGREN, S. \& FIRESTEIN, G.S. (1996). Spinal cord adenosine stimulation in rats inhibits peripheral neutrophil accumulation. The role of $\mathrm{N}$-methyl-D-aspartate receptors. $J$. Clin. Invest., 12, $2779-2785$.

BOREA, P.A., DALPIAZ, A., VARANI, K., GUERRA, L. \& GILLI, G. (1995). Binding thermodinamics of adenosine $A_{2 A}$ receptor ligands. Biochem. Pharmacol., 49, 461-469.

BRADFORD, M.M. (1976). A rapid and sensitive method for the quantitation of microgram quantities of protein utilizing the principle of protein dye-binding. Anal. Biochem., 72, 248.
BROWN, B.L., ALBANO, J.D.M., EKINS, R.I. \& SGHERZI, A.M. (1971) A simple and sensitive saturation assay method for the measurement of adenosine $3^{\prime}: 5^{\prime}$-cyclic monophosphate. Biochem. J., 121, 561-562.

BRUNS, R.F., FERGUS, J.H., BADGER, E.W., BRISTOL, J.A., SANTAY, L.A. \& HAYS, S.J. (1987). PD 115,199: an antagonist ligand for adenosine $\mathrm{A}_{2}$ receptors. Naunyn-Schmiedeberg's Arch. Pharmacol., 335, 64-69.

CHENG, Y.C. \& PRUSOFF, W.H. (1973). Relationships between the inhibition constant $\left(\mathrm{K}_{\mathrm{i}}\right)$ and the concentration of inhibitor which causes 50 per cent inhibition $\left(\mathrm{IC}_{50}\right)$ of an enzymatic reaction. Biochem. Pharmacol., 22, 3099-3108.

CRONSTEIN, B.N. (1994). Adenosine, an endogenous anti-inflammatory agent. J. Appl. Physiol., 76, 5-13.

CRONSTEIN, B.N., DAGUMA, L., NICHOLS, D., HUTCHISON, A.J. \& WILliAMS, M. (1990). The adenosine/neutrophil paradox resolved: human neutrophils possess both $\mathrm{A}_{1}$ and $\mathrm{A}_{2}$ receptors that promote chemotaxis and inhibit $\mathrm{O}_{2}$ generation, respectively. J. Clin. Invest., 85, $1150-1157$. 
CRONSTEIN, B.N., HAINES, K.A., KOLASINSKI, S. \& REIBMAN, J. (1992). Occupancy of $\mathrm{G}$ alpha s-linked receptors uncouples chemoattractant receptors from their stimulus-transduction mechanisms in the neutrophil. Blood, 80, 1052-1057.

CRONSTEIN, B.N. \& HIRSCHHORN, R. (1990). Adenosine and host defense. Modulation through metabolism and receptor-mediated mechanisms. In Adenosine and Adenosine Receptors. Ed. Williams, M. New Jersey: The Humana Press Inc.

CRONSTEIN, B.N., ROSENSTEIN, E.D., KRAMER, S.B., WEISSMAN, G. \& HIRSCHHORN, R. (1985). Adenosine: a physiologic modulator of superoxide anion generation by human neutrophils. Adenosine acts via an $\mathrm{A}_{2}$ receptor on human neutrophils. $J$. Immunol., 135, 1366-1371.

DIONISOTTI, S., FERRARA, S., MOLTA, C., ZOCCHI, C. \& ONGINI, E. (1996). Labeling of $A_{2 A}$ adenosine receptos in human platelets using the new non-xanthine antagonist radioligand $\left[{ }^{3} \mathrm{H}\right]-\mathrm{SCH}$ 58261. J. Pharmacol. Exp. Ther., 298, 726-732.

DIONISOTTI, S., ONGINI, E., ZOCCHI, C., KULL, G., ARSLAN, G. \& FREDHOLM, B.B. (1997). Characterization of human $\mathrm{A}_{2 \mathrm{~A}}$ adenosine receptors using the antagonist radioligand $\left[{ }^{3} \mathrm{H}\right]-\mathrm{SCH}$ 58261. Br. J. Pharmacol., (in press)

FINNEY, D.J. (1978). Statistical Methods in Biological Assay. ed. Grin. pp. 80-82. London: Griffin \& Co.

FREDHOLM, B.B., ABBRACCHIO, M.P., BURNSTOCK, G., DALY, J.W., HARDEN, T.K., JACOBSON, K.A., LEFF, P. \& WILLIAMS, M. (1994). Nomenclature and classification of purinoceptors. Pharmacol. Rev., 46, $143-156$.

FREDHOLM, B.B., ZHANG, Y. \& VAN DER PLOEG, I. (1996). Adenosine $A_{2 A}$ receptors mediate the inhibitory effect of adenosine on formyl-Met-Leu-Phe-stimulated respiratory burst in neutrophil leukocytes. Naunyn-Schmiedeberg's Arch. Pharmacol., 354, $262-267$.

GILLI, P., FERRETTI, V., GILLI, G. \& BOREA, P.A. (1994). Enthalpyentropy compensation in drug-receptor binding. J. Phys. Chem., 98, $1515-1518$.

HUSSAIN, T. \& MUSTAFA, S.J. (1993). Regulation of the adenosine receptor system in coronary artery: functional studies and cAMP. Am. J. Physiol., 33, H 441.

HUTCHISON, K.A., NERVIS, B., PERINI, F. \& FOX, I.H. (1990). Soluble and membrane-associated human low-affinity adenotin binding protein (adenotin): properties and homology with mammalian and avian stress proteins. Biochemistry, 29, $5138-$ 5144.

LIANG, B.T. (1992). Adenosine receptors and cardiovascular function. Trends Cardiovasc. Med., 2, 100.

LINDSTRÖM, K., ONGINI, E. \& FREDHOLM, B.B. (1996). The selective adenosine $\mathrm{A}_{2 \mathrm{~A}}$ receptor antagonist $\mathrm{SCH} 58261$ discriminates between two different binding sites for $\left[{ }^{3} \mathrm{H}\right]-\mathrm{CGS}$ 21680 in the rat brain. Naunyn-Schmiedeberg's Arch. Pharmacol., 354, 539-541.

LOHSE, M.J., ELGER, B., LINDEBORN-FOTINOS, J., KLOTZ, K.N. \& SCHWABE, U. (1988). Separation of solubilized $\mathrm{A}_{2}$ adenosine receptors of human platelets from non-receptor $\left[{ }^{3} \mathrm{H}\right]$ NECA binding sites by gel filtration. Naunyn-Schmiedeberg's Arch. Pharmacol., 337, 64-68.

MARKERT, M., ANDREWS, P.C. \& BABIOR, B.M. (1984). Measurement of $\mathrm{O}_{2}-$ production by human neutrophils. The preparation and assay of NADPH oxidase-containing particles from human neutrophils. Methods Enzymol., 105, 358-365.
MUNSON, P.J. \& RODBARD, D. (1980). Ligand: a versatile computerized approach for the characterization of ligand binding systems. Anal. Biochem., 107, 220-239.

NANOFF, C., JACOBSON, K.A. \& STILES, G.L. (1991). The A $_{2}$ adenosine receptor: guanine nulceotide modulation of agonist binding is enhanced by proteolysis. Mol. Pharmacol., 39, 130135.

NANOFF, C. \& STILES, G.L. (1993). Solubilization and characterization of the $\mathrm{A}_{2}$-adenosine receptor. J. Receptor Res., 13, 961 - 973.

NONAKA, H., MORI, A., ICHIMURA, M., SHINDOU, T., KANAGAWA, H., SHIMADA, J. \& KASE, H. (1994). Binding of $\left[{ }^{3} \mathrm{H}\right]$ KF17837S, a selective adenosine $\mathrm{A}_{2}$ receptor antagonist, to rat brain membranes. Mol. Pharmacol., 46, 817-822.

NORDSTEDT, C. \& FREDHOLM, M.M. (1990). A modification of a protein-binding method for rapid quantification of cAMP in cell culture supernatants and body fluids. Anal. Biochem., 189, 231 234

OLAH, M.E. \& STILES, G.L. (1995). Adenosine receptor subtypes: Characterization and Therapeutic Regulation. Ann. Rev. Pharmacol. Toxicol., 35, 581-588.

ONGINI, E. \& FREDHOLM. B.B. (1996). Pharmacology of adenosine $\mathrm{A}_{2 \mathrm{~A}}$ receptors. Trends Pharmacol. Sci., 17, 364-372.

RUDOLPHI, K.A., SCHUBERT, P., PARKINSON, F.E. \& FREDHOLM, B.B. (1992). Neuroprotective role of adenosine in cerebral ischemia. Trends Pharmacol. Sci., 13, 439-445.

SCATCHARD, G. (1949). The attractions of protein for small molecules and ions. Ann. New York Acad. Sci., 51, 660-672.

SCHRIER, D.J. \& IMRE, K.M. (1986). The effects of adenosine on human neutrophil function. J. Immunol., 137, 3284-3288.

SPISANI, S., GIULIANI, A.L., CAVALLETTI, T., ZACCARINI, M., MILANI, L., GAVIOLI, R. \& TRANIELLO, S. (1992). Effect of cyclic AMP level reduction on human neutrophil responses to formylated peptides. Inflammation, 16, 147-158.

VARANI, K., GESSI, S., DALPIAZ, A. \& BOREA, P.A. (1996). Pharmacological and biochemical characterization of purified $\mathrm{A}_{2 \mathrm{~A}}$ adenosine receptor in human platelet membranes by $\left[{ }^{3} \mathrm{H}\right]$ CGS 21680 binding. Br. J. Pharmacol., 117, 1693-1701.

VARANI, K, GESSI, S, DALPIAZ, A \& BOREA, P.A. (1997). Characterization of $\mathrm{A}_{2 \mathrm{~A}}$ adenosine receptor in human lymphocyte membranes by $\left[{ }^{3} \mathrm{H}\right] \mathrm{SCH} 58261$ binding. Br. J. Pharmacol. 122, 386-392.

ZHANG, Y. \& FREDHOLM, B.B. (1994). Propentophylline enhancement of the actions of adenosine on neutrophil leukocytes. Biochem. Pharmacol., 48, 2025-2032.

ZOCCHI, C., ONGINI, E., CONTI, A., MONOPOLI, A., NEGRETTI, A., BARALDI, P.G. \& DIONISOTTI, S. (1996a). The non-xanthine heterocyclic compound SCH 58261 is a new potent and selective $\mathrm{A}_{2 \mathrm{~A}}$ adenosine receptor antagonist. J. Pharmacol. Exp. Ther., 276, $398-404$

ZOCCHI, C., ONGINI, E., FERRARA, S., BARALDI, P.G. \& DIONISOTTI, S. (1996b). Binding of the radioligand $\left[{ }^{3} \mathrm{H}\right]-\mathrm{SCH} 58261$, a new non-xanthine $\mathrm{A}_{2 \mathrm{~A}}$ adenosine receptor antagonist, to rat striatal membranes. Br. J. Pharmacol., 117, 1381-1386.

(Received September 9, 1997 Revised January 5, 1998 Accepted January 8, 1998) 